\title{
Homologous Sequences with a Plasmid pJTPS1 Are Contained in Pseudomonas solanacearum Isolated from Tobacco in Japan
}

\author{
Hideaki Negishi* Hiroshi Tanaka*, Hatsue MaEdA** \\ and Tetsuji YAMADA***
}

Key words: Pseudomonas solanaceant, biovar, bacterial group, tobacco, RFLP.

Bacterial wilt caused by Pseudomonas solanacearum (Smith) Smith is one of the most destructive diseases in solanaceous plant fields. We have previously reported that a circular double-stranded DNA plasmid pJTPS1 carrying unique restriction endonuclease sites existed in $P$. solanacearum $\mathrm{M}_{4} \mathrm{~S}^{7}$, a spontaneous non-pathogenic mutant from $P$. solanacearum U. $7^{11}$. This plasmid was thought to be excised from genomic DNA or megaplasmid DNA in the parental pathogenic strain of U. $7^{71}$ and autonomously replicated by an unknown mechanism. We showed the evidences that the presence of a small plasmid pJTPS1 correlated to the shift of the phenotypic changes (pathogenicity, colony morphology, extracellular polysaccharide (EPS) production and endoglucanase (EG) activity) in the spontaneous mutation of $P$. solanacearum and it was postulated that a small plasmid pJTPS1 carried nonpathogenicity factor for bacterial wilt disease ${ }^{6}$. However, it has not been elucidated whether the homologous sequences with pJTPS1 generally exists in the genome or megaplasmid of pathogenic isolates of $P$. solanacearum.

It has been reported that there are five bacterial groups in $P$. solanacearum isolated from eggplant in Japan based on the different aggressiveness to eggplant and its stocks ${ }^{8}$. Biovar is another standard to classify strains of $P$. solanacearum ${ }^{4}$ by the ability to utilize sugars. However, the bacterial group or biovar of tobacco isolates in Japan have not been well characterized.

This paper describes 1) the investigation of bacterial groups and biovars of $P$. solanacearum isolated from tobacco in Japan, and 2) the existence of the homologous sequences with pJTPS1 in a variety of strains of the bacterium.

Strains of $P$. solanacearum were isolated from diseased plants or soil of tobacco fields by growing on the modified GS medium ${ }^{2.12}$. Isolated bacteria (186 strains) were routinely grown on Kelman's TZC medium $^{51}$ at $30^{\circ} \mathrm{C}$ for 3 days and stored in sterilized distilled water at room temperature. Bacterial group of these strains was investigated according to the method of Ozaki and Kimura ${ }^{8}$. Biovar of these strains was investigated according to the method of Hayward ${ }^{4}$. The number of strains isolated from different geographical areas and their bacterial groups are listed in Table 1. The largest population belonged to bacterial group II ( $41.9 \%)$ followed to III, IV, V and I (35.5\%, $17.7 \%, 3.8 \%$ and $1.1 \%$, respectively). One hundred seventy-seven out of 186 strains belonged to biovar III and the rest to biovar II. No strain belonged to biovar I, IV or V. There was no distinct relationship between the areas of isolation and bacterial groups or biovars.

Fifty-five strains of $P$. solanacearum were chosen for RFLP analysis based upon geographical

- Japan Tobacco Inc., Applied Plant Research Laboratory, Yokohama Center, 6-2 Umégaoka, Midori-ku. Yokohama 227, Japan日本たばこ(怢)植物開発研究所横浜センター

** Japan Tobacco Inc., Applied Plant Research Laboratory, 1900 Idei, Oyama 323. Japan日本たばこ(株)植物 開発研究所

** Laboratory of Plant Pathology, College of Agriculture, Okayama University, 1-1-1 Tsushimanaka, Okayama 700, Japan 岡山大学農学部 
Table 1. The bacterial groups of $P$. solanaceanum isolated from tobacco and tobacco fields in Japan

\begin{tabular}{lcccccc}
\hline \hline \multirow{2}{*}{ Area } & Total & \multicolumn{5}{c}{ Bacterial group } \\
\cline { 3 - 7 } & number & I & II & III & IV & V \\
\hline Northern Japan & 45 & 1 & 22 & 10 & 8 & 4 \\
Eastern Japan & 74 & 0 & 33 & 25 & 13 & 3 \\
Western Japan & 24 & 0 & 11 & 11 & 2 & 0 \\
Southern Japan & 43 & 1 & 12 & 20 & 10 & 0 \\
\hline \multicolumn{1}{c}{ Total } & 186 & 2 & 78 & 66 & 33 & 7 \\
& & $(1.1 \%)$ & $(41.9 \%)$ & $(35.5 \%)$ & $(17.7 \%)$ & $(3.8 \%)$ \\
\hline
\end{tabular}

Table 2. DNA : DNA hybridization analysis of strains of $P$. solanacearum with pJTPS1 as a probe, the location of their isolation and their bacterial group

\begin{tabular}{|c|c|c|c|c|c|c|c|}
\hline $\begin{array}{l}\# \text { of } \\
\text { strain }\end{array}$ & Prefecture & $\begin{array}{l}\text { Bacterial } \\
\text { group }\end{array}$ & $\begin{array}{l}\text { RFLP } \\
\text { type* }\end{array}$ & $\begin{array}{c}\text { \# of } \\
\text { strain }\end{array}$ & Prefecture & $\begin{array}{c}\text { Bacterial } \\
\text { group }\end{array}$ & $\begin{array}{c}\text { RFLP } \\
\text { type }\end{array}$ \\
\hline $\mathrm{U} \cdot 7$ & Tochigi & III & I & 186 & Toyama & IV & 1 \\
\hline 213 & Akita & II & I & 232 & Ishikawa & II & I \\
\hline 322 & Akita & III & I & 191 & Ishikawa & III & I \\
\hline 212 & Akita & IV & I & 23 & Fukui & IV & I \\
\hline 324 & Akita & V & I & 207 & Shiga & II & I \\
\hline 250 & Iwate & II & I & 113 & Hyougo & II & I \\
\hline 248 & Yamagata & II & I & 160 & Okayama & II & I \\
\hline 158 & Yamagata & IV & I & 204 & Tottori & III & II \\
\hline 230 & Miyagi & II & I & 118 & Shimane & III & I \\
\hline 195 & Fukushima & II & I & 197 & Hiroshima & II & I \\
\hline 193 & Fukushima & III & I & 117 & Hiroshima & III & II \\
\hline 194 & Fukushima & IV & I & 199 & Yamaguchi & III & - \\
\hline 284 & Fukushima & $\mathrm{V}$ & I & 20 & Yamaguchi & IV & I \\
\hline 10 & Tochigi & I & I & 116 & Tokushima & II & I \\
\hline 164 & Tochigi & II & I & 157 & Tokushima & III & II \\
\hline 21 & Tochigi & III & I & 189 & Kagawa & II & I \\
\hline 226 & Tochigi & IV & I & 114 & Ehime & II & I \\
\hline 162 & Ibaraki & II & I & 154 & Kouchi & II & - \\
\hline 276 & Ibaraki & V & I & 111 & Kouchi & III & I \\
\hline 275 & Ibaraki & III & I & 161 & Kouchi & IV & - \\
\hline 166 & Ibaraki & IV & 1 & 224 & Nagasaki & I & II \\
\hline 168 & Chiba & II & I & 142 & Nagasaki & III & - \\
\hline 155 & Shizuoka & III & II & 123 & Kumamoto & II & I \\
\hline 214 & Niigata & II & 1 & 180 & Kumamoto & III & - \\
\hline 215 & Niigata & IV & II & 130 & Kumamoto & IV & I \\
\hline 247 & Niigata & $\mathrm{V}$ & I & 125 & Miyazaki & III & I \\
\hline 183 & Nagano & II & I & 108 & Kagoshima & III & - \\
\hline 234 & Toyama & II & I & & & & \\
\hline
\end{tabular}

${ }^{*}$ RFLP type

I : At least three PstI fragments $(3.8,1.1$ and $0.5 \mathrm{~kb})$ hybridized with $\mathrm{pJTPS} 1$

II : At least four PstI fragments $(3.8,1.1,0.5$ and $1.2 \mathrm{~kb}$ ) hybridized with pJTPS1

- : No fragment hybridized with pJTPS1

distribution and bacterial groups. By using total DNA isolated from these strains and U-7 as a standard, DNA : DNA blot hybridization analysis was performed with pJTPS1 digested with $P_{s t} \mathrm{I}$ as a probe. The total DNAs, including genome, megaplasmid(s) and small plasmid(s), of these strains were isolated by the procedure described by $\mathrm{Xu}$ et al. ${ }^{13)}$ except that isopycnic centrifugation in CsCl-ethidium bromide was omitted. After the treatment with RNaseI (Sigma), $5 \mu \mathrm{g}$ of the total DNA was digested with Pst I and subjected to electrophoresis on a $0.7 \%$ agarose gel in TBE buffer. For DNA labeling, blotting and 


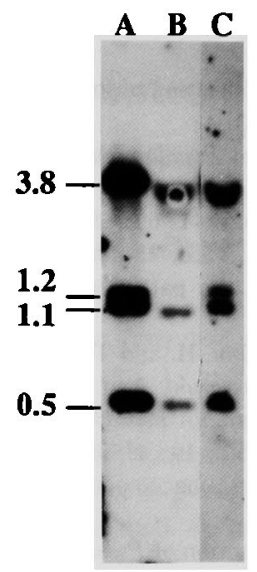

Fig. 1. DNA : DNA blot hybridization analysis of total DNA from Pseudomonas solanacearum with pJTPS1 as a probe. The lanes consist of pJTPS1 (lane A), total DNA extracted from $P$. solanaceanum U-7 [RFLP type I] (lane B) and a strain number 157 [RFLP type II] (lane C). The numbers on the left denote the size (in $\mathrm{kb}$ ) of the DNA fragments.

DNA hybridization, non radioactive DNA Labeling and Detection $\mathrm{Kit}^{\mathrm{TM}}$ (Boehringer Mannheim Yamanouchi Inc.) and Southern Light ${ }^{\mathrm{TM}}$ (Tropix Inc.) were used according to the manufacture's specification. U-7 had at least five PstI fragments hybridizing to pJTPS1 and the three PstI fragments positioned at 3.8, 1.1 and $0.5 \mathrm{~kb}$ were identical to those of $\mathrm{pJTPS1}^{7}$ (Fig. 1, lane B). RFLP analysis of these DNAs with a plasmid, pJTPS1, as a probe were shown in Table 2. Forty-nine strains out of 55 had homologous sequences with pJTPS1. Furthermore, 43 strains including U-7 had at least three Pst I fragments $(3.8,1.1$ and $0.5 \mathrm{~kb}$ ) hybridized with pJTPS1 (RFLP type I). Six strains had an additional Pst I fragment (1.2 kb) hybridized with pJTPS1 (RFLP type II) (Fig. 1, lane C). Six strains had no homologous sequences with pJTPS1 and all of them were isolated in western Japan. There was no clear correlation between the locations of isolation and bacterial groups by RFLP analysis. These data suggest that homologous sequences with pJTPS1 commonly exist in $P$. solanacearum, and most of these sequences are same in length. $P$. solanacearum of RFLP type II may have the duplicate homologous sequences with pJTPS1.

In this paper, we have demonstrated that $P$. solanacearum isolated from tobacco in Japan commonly possesses the homologous sequences with pJTPS1 regardless of the locations of isolation and their bacterial groups. pJTPS1 is thought to carry non-pathogenicity factor which is involved in phenotype changes of $P$. solanacearum. Gene(s) on pJTPS1 may be free from the control and/or regulation mechanism which suppresses the expression of the corresponding gene(s) on the genome or megaplasmid, ultimately resulting in the phenotypic change of wild type ${ }^{6}$. Therefore, almost all strains of $P$. solanacearum may change their phenotypes (pathogenicity, colony morphology, EPS production, EG activity etc.) by the same mechanism as M4S. It still may be possible that the strains possessing no homologous sequences with pJTPSl change their phenotypes, because the gene(s) or region involving in phenotypic change is not only pJTPS1 but also $p h c A^{11}$ and $e p s R^{3}$. It is interesting to investigate what kind of phenotypic change will occur in these strains, if they may be mutated by pJTPS1. Studies are under way to determine the entire DNA sequence of PJTPSI and to characterize the role of the genes responsible for spontaneous mutation in pathogenicity.

\section{Literature cited}

1. Brumbley, S.M. and Denny, T.P. (1990). Cloning of wild-type Pseudomonas solanaceanum phcA, a gene that when mutated alters expression of multiple traits that contribute to virulence. J. Bacteriol. 172:5677-5685. 
2. Granada, G.A. and Sequeira, L. (1983). A new selective medium for Pseudomonas solanacearum. Plant Dis. $67: 1084-1088$.

3. Huang, Y. and Sequeira, L. (1990). Identification of locus that regulates multiple functions in Pseudomonas solanaceanim. J. Bacteriol. 172 : 4728-4731.

4. Hayward, A.C. (1964). Characteristics of Pseudomonas solanacearum. J. Appl. Bact. 27: $265-277$.

5. Kelman, A. (1954). The relationship of pathogenicity of Pseudomonas solanaceamim to colony appearance on a tetrazorium medium. Phytopathology $44: 693-695$.

6. Negishi, H., Yamada, T., Shiraishi, T., Oku, H. and Tanaka, H. (1993). Pseudomonas solanacearum: plasmid pJTPSI mediates a shift from the pathogenic to non-pathogenic phenotype. Molecular PlantMicrobe Interactions $6: 203-209$.

7. Negishi, H., Yamada, T., Shiraishi, T., Oku, H. and Tanaka, H. (1990). A small plasmid isolated from an avirulent mutant of Pseudomonas solanaceanm. Ann. Phytopath. Soc. Japan. 56: 687-690.

8. Ozaki, K. and Kimura, T. (1992). Grouping of Pseudomonas solanacearum on the basis of pathogenicity to plants. Bull. Chugoku Nat. Agri. Expt. Sta. $10: 49-58$.

9. Tanaka, H. (1985). Induced resistance in tobacco against bacterial wilt and its possible mechanism. Bull. Utsunomiya Tob. Expt. Sta. $21: 1-66$.

10. Tanaka, H. and Fukuda, N. (1982). Detection of Pseudomonas solanacearum in infested soils by a selective medium and a bioassay. Bull. Utsunomiya Tob. Expt. Sta. 19: 1-10.

11. Xu, P., Leong, S. and Sequeira, L. (1988). Molecular cloning of genes that specify virulence in Pseudomonas solanacearum. J. Bacteriol. $70: 617-622$.

\section{和 文 摘 要}

根岸秀明・田中 博・前田初枝・山田哲治：日本各地のタバコから分離したPseudomonas solanacearumにわけるプ ラスミドpJTPS 1 相同性配列の存在

日本各地の夕バコから 186 菌株のP. solanacearum を分離した。これらの菌株について,ナスとナス台木に対する病 原性をもとにした菌群, 生理型(biovar)を調べた。菌群は II 型が最も多く次いでIII, IV, I の順であった。生理型は ほとんどの菌株がIII型であり，そのほかわずかにII 型が存在した。分離された地域と菌群および生理型には明確な関 係は認められなかった。これらの菌株から菌群と分離地域が異なる55 菌株を選び, 全 DNA を抽出し, 非病原性菌株 M4S由来のプラスミド pJTPS1をプローブとしたDNA：DNAブロットハイブリダイゼーションを行ったところ， 49 菌株が pJTPS 1 と相同性を示し, そのうち 43 菌株は M 4 S の親株U.7 と同様に, 少なくとも 3 本のPstI消化 DNA 断片 $(3.8,1.1$ and $0.5 \mathrm{~kb})$ が pJTPS 1 と相同性を示した。これら 3 本の DNA 断片に加えて $1.2 \mathrm{~kb} の \mathrm{pJTPS} 1$ と相同性を示す PstI 消化断片を持つものが 6 菌株存在した。pJTPS 1 に対する相同性部位の有無に関する RFLP解 析では，地域や菌群との明確な関係は諗められず, pJTPS 1 との相同性部位は病原性のP. solanacearum に広く全般 的に存在していた。

(Received December 8, 1992) 